\title{
Impact of Bank Credit on Real Sector Growth in Nigeria
}

\author{
AJAYI Foluso Isaac, AKOSILE Mary Oluwayemisi and ADEGOKE Temitope Damilola \\ Department of Finance, Ekiti State University, Ado-Ekiti \\ Emails: foluso.ajayi@eksu.edu.ng, mary.akosile@eksu.edu.ng, adegoke.temitope@eksu.edu.ng
}

\begin{abstract}
This study examined the impact of bank credit on real sector growth in Nigeria from 1986 to 2019. Times series data was used for the study. Ordinary least square, ARDL and ECM were used to analyze the data. In this study, Agricultural Output (AGO) and Manufacturing Output (MANO) were used as proxy for real sector growth while Bank Credit proxies were Credit to Private Sector (CPS), Inflation Rate (INF) and Lending Rate (LDR). The result of the ordinary least square revealed that CPS was positively and significantly related to the real sector, INF was negatively and insignificantly related to the real sector, while LDR was found to be positively and significantly related to the real sector. However, the result of ARDL from Bound Test showed that there was long run relationship between bank credit and the real sector. Also, the result from ECM through impulse response function revealed that the credit to private sector and inflation rate move in positive and negative directions but closer to zero. While lending rate moves in negative direction away from zero. The study concluded that the real sector is positively influenced by credit to private sector with little contribution. Whereas, inflation rate was inversely related to the real sector. Lastly, the lending rate responded negatively and moved further away from zero in the impulse from the real sector. The study therefore recommended that the CBN should increase the proportion of credit to private sector and at the same time control lending rate. Also, machinery to meet up with the targeted inflation rate must be put in place.
\end{abstract}

Keywords: Agricultural output, manufacturing output, inflation, lending rate, credit to private sector, ordinary least square.

DOI: $10.7176 / \mathrm{EJBM} / 14-4-03$

Publication date: February $28^{\text {th }} 2022$

\section{INTRODUCTION}

Bank credit is the loan and advances given to individual or corporate bodies by financial institutions which form part of the capital required in the business (Ajayi 2000). Capital is the most important factor of production since other factors like land, labour and human resources can be acquired through it. Capital is needed to acquire raw materials, machineries, technology and payment of wages. Therefore, the real sector is greatly affected by the availability of funds which could be sourced from either equity or debt. The equity is the owner's stake in the business most of the time it is sourced by issuing of financial securities in the capital market. Meanwhile, debt is the funds acquired from financial institutions like deposit money bank, merchant bank, microfinance bank and so on which can be inform of loan and overdraft. Savings are not always enough for the desired level of investment therefore, there is always need to borrow fund from financial institutions in order to fill the savings and investment gap.

However, availability of credit to individual and corporate investors in the economy is affected majorly by interest rate, lending rate, inflation rate and other factors determined by influence of demand and supply and the Central bank through monetary policy.

Accessibility of funds for is a major challenge faced by the manufacturing sector in Nigeria this has affected its performance in recent years (Edirisuriya, 2008). Nigerian government employed a number of strategies that were aimed at enhancing availability of credit to the sector which will translate to growth. Some of these strategies were the restrictive monetary policy, the structural adjustment program of 1986 and concessional rates on duty on raw material importation (Aiyedogbon \& Anyanwu, 2015). Others include the Small Scale Industries Credit Scheme (1971), establishment of Industrial Development Centres, National Economic Reconstruction Fund (NERFUND), Nigerian Bank for Commerce and Industries, Nigerian Industrial Development Bank (NIDB) which was reconstructed in 2001 to Bank of Industry (BOI) with a mandate of transforming Nigeria's industrial sector through the provision of financial and business support services to enterprises so as to improve the performance of the sector. The sum of N200 billion was made available as Manufacturers' Intervention Fund in 2010 through the Central Bank of Nigeria (Ebele \& Iorember 2016). Others include National Programme on Food Security (NPFS), cassava bread fund, cement fund, cottage fund, rice and cassava intervention fund, sugar development council fund and so on.

Despite the various policy measures to enhance the growth of real sector in Nigeria by subsequent governments, their impacts have not been fully felt by the sector, rather, the manufacturing sector has been experiencing a diminutive growth with low contribution to gross domestic product. This may be due to high lending rate and the inability to secure loans due to stringent conditions like collateral requirement. 
The objective of this study is to examine the contribution of bank credit on the growth of agricultural as well as manufacturing sub-sectors in Nigeria.

\section{LITERATURE REVIEW}

Andabai and Eze (2018) investigated the causality of bank credit on manufacturing sector growth in Nigeria over a period of 1990 to 2016. The study employed Johansen co-integration test and Vector Error Correction Model to analyze the data. The result showed a significant relationship between bank credit and manufacturing sector growth in the short run. Also, no causal relationship between bank credit and manufacturing sector growth in Nigeria. The study concluded that there was no significant contribution by bank credit to manufacturing sector growth in Nigeria.

Ebele and Iorember (2016) accessed the effect of commercial bank credit on the manufacturing sector output in Nigeria between 1980 and 2015. Augmented Dickey Fuller and Cochrane-Orcutt method were used. The study found that, inflation rate and interest rate have negative effect on manufacturing sector output while loans and advances and broad money supply have positive effect with manufacturing sector output in Nigeria.

Ananzeh (2016) examined the relationship between bank credit and economic growth in Jordan at different sector from 1993 to 2014. The study employed Vector Error Correction Model (VECM) and Granger Causality Test. The results showed that that the efficiency of the bank credit facilities in a major economic sector has an important role in the Jordanian economic growth.

Lorenzo and Daryna (2015) evaluated the interdependence between financial development and real sector output and the effect on economic growth of developed and developing countries from1970 to 2010. Panel data was used in analyzing the data. The result showed that economic growth depends on the growth of private credit.

Oni, Akinlo and Oladepo (2014) examined the impact of bank credit to output growth in the manufacturing and agricultural sub sectors of the Nigerian economy from 1980-2010. The error correction modeling (ECM) techniques was adopted in the study. The results of the study showed that bank credit has significant impact on manufacturing output growth both in the short run and long run but not in the agricultural sub sector. Inflation and exchange rate depreciation have negative effects on manufacturing output growth in both short run and long run.

Adenugba (2015) investigated the reasons why bank lending or access to credit by Small and Medium Scale Enterprises (SME) has remained low in Nigeria. Ordinary Least Square (OLS) technique was adopted. The result showed that banking system credit is indeed an instrument of economic growth in Nigeria. It was concluded that, increase in savings leads to availability of credits for individuals, government, entrepreneurs, private and public sector which will enhance economic growth.

\section{RESEARCH METHOD}

Model Specification

The study modified the model used by Emecheta and Ibe (2014) which expressed GDP growth rate as functions of Bank Credit to the private sector and money supply.

$\mathrm{GDP}=f(\mathrm{BCPS}, \mathrm{M} 2)$

Where

GDP $=$ Gross Domestic Product at current basic prices

$\mathrm{BCPS}=$ Bank Credit to the private sector

Equation1 is modified for the purpose of this study by developing two models where agricultural and manufacturing output are dependent variables and the inclusion of lending rate and inflation rate in the dependent variables.

The modified models are:

$\mathrm{AGO}=f(\mathrm{CPS}, \mathrm{INF}, \mathrm{LDR})$

MANO $=f($ CPS, INF, LDR $)$

Where:

AGO = Agricultural Output

MANO = Manufacturing Output

CPS $=$ Credit to Private Sector

$\mathrm{INF}=$ Inflation

$\mathrm{LDR}=$ Lending rate

$\mathrm{F}=$ functional denotation

The econometric models are presented as:

$A G O_{t}=\beta_{0}+\beta_{1} C P S_{t}+\beta_{2} I N F_{t}+\beta_{3} L D R_{t}+\mu_{t}$.

$M A N O_{t}=\beta_{0}+\beta_{1} C P S_{t}+\beta_{2} I N F+\beta_{3} L D R_{t}+\mu_{t}$

Whereas the log form of the models are: 
$\log A G O_{t}=\beta_{0}+\beta_{1} \log C P S_{t}+\beta_{2} \log I N F_{t}+\beta_{3} \log L D R_{t}+\mu_{t}$

$\log$ MANO $_{t}=\beta_{0}+\beta_{1} \log C P S_{t}+\beta_{2} \operatorname{logINF} F_{t}+\beta_{3} \log L D R_{t}+\mu_{t}$

Where:

$\log =$ Logarithm

$$
\mathrm{t}=\text { at time } \mathrm{t}
$$

$\beta_{0}=$ Constant parameter/Intercept

$\beta_{1}-\beta_{3}=$ Coefficients of independent variables

$$
\mu=\text { Error term }
$$

\section{A priori Expectation}

$\frac{\partial \mathrm{AGO} / \mathrm{MAN}>0 ;}{\partial \mathrm{CPS}} \frac{\partial \mathrm{AGO} / \mathrm{MAN}<0 ;}{\partial \mathrm{INF}} \frac{\partial \mathrm{AGO} / \mathrm{MAN}<0}{\partial \mathrm{LDR}}$

\section{Estimation Techniques}

The estimation techniques in data analysis are unit root test, ordinary least square, ARDL and ECM

\section{Source of Data}

Time series data which were majorly sourced from the statistical bulletin of the Central Bank of Nigeria (CBN), from 1986 to 2019 were used in the study.

\section{Results and Discussion of Findings \\ Agricultural Sector \\ Descriptive Analysis}

Table 1.0 Result of Descriptive Analysis

\begin{tabular}{|l|c|c|c|c|}
\hline & AGO & \multicolumn{1}{l|}{ CPS } & \multicolumn{1}{l|}{ INF } \\
\hline Mean & 7018.209 & 11.55074 & 19.69049 & 18.74165 \\
\hline Median & 3133.471 & 8.249338 & 12.07481 & 18.06625 \\
\hline Maximum & 27371.30 & 20.77330 & 76.75887 & 31.65000 \\
\hline Minimum & 34.23709 & 6.217349 & 0.223606 & 9.433333 \\
\hline Std. Dev. & 8169.478 & 5.473608 & 18.91575 & 4.150861 \\
\hline Skewness & 0.981715 & 0.714269 & 1.675673 & 0.561096 \\
\hline Kurtosis & 2.716532 & 1.692454 & 4.681582 & 4.952936 \\
\hline Jarque-Bera & 5.575163 & 5.313064 & 19.91726 & 7.187139 \\
\hline Probability & 0.061570 & 0.070191 & 0.000047 & 0.027500 \\
\hline Sum & 238619.1 & 392.7252 & 669.4767 & 637.2162 \\
\hline Sum Sq. Dev. & $2.20 \mathrm{E}+09$ & 988.6926 & 11807.58 & 568.5784 \\
\hline Observations & 34 & 34 & 34 & 34 \\
\hline
\end{tabular}

Source: Author's computation (2020)

The descriptive statistics presented in Table 1 shows the mean value of agricultural output (AGO) as 7018.209 and varies from a minimum of 34.23709 to a maximum of 27371.30 Credit to private sector (CPS) has a mean of 11.55074 and ranges from 6.217349 to a maximum of 20.77330 . The mean of inflation rate (INF) is 19.69049 and it exhibits a minimum of 0.223606 and maximum of 76.75887 , whereas the mean value of lending rate mean is 18.74165 with a minimum of 9.433333 to a maximum of 31.65000 . However, the Skewness statistic indicates that all the variables are positively skewed. Kurtosis statistic reveals that AG is mesokurtic, INF and LDR are leptokurtic while CPS is platykurtic in nature. The Jarque-Bera statistic reveals that AG and CPS mirror normal distribution while INF and LDR are not normally. 
Ordinary Least Square Result

Table 2.0 OLS Result

\begin{tabular}{|l|l|l|l|l|}
\hline Variables & Co-efficient & Std. Error & T-statistics & Prob. \\
\hline C & -8.494043 & 3.511281 & -2.419072 & 0.0218 \\
\hline LogCPS & 3.941548 & 0.538135 & 7.324461 & 0.0000 \\
\hline LogINF & -0.313578 & 0.225006 & -1.393643 & 0.1737 \\
\hline LogLDR & 2.598781 & 1.097722 & 2.367432 & 0.0246 \\
\hline R-squared & 0.650051 & & \\
\hline Adjusted R-squared & 0.615056 & \multicolumn{4}{|l|}{} \\
\hline F-statistic & 18.57557 & Durbin-Watson stat & 0.535222 \\
\hline Prob (F-statistic) & 0.000001 & \multicolumn{3}{|l|}{} \\
\hline
\end{tabular}

Source: Authors computation, (2020)

The result from Table 2.0 shows that beta coefficient of agricultural output (AGO) is negative at constant of -8.494043 which means that when all variables are held constant; there will be a negative variation to the tune of -8.494043 units in agricultural output. The coefficient value of credit to private sector (CPS) is 3.941548 with Pvalue of 0.0000 meaning that CPS has a positive and significant impact on AGO. -0.313578 and 0.1737 are the coefficient value and P-value of inflation rate which means that inflation rate impacted negatively and insignificantly on AGO throughout the period. Whereas, lending rate has a coefficient value of 2.598781 and Pvalue of 0.0246 which implies that lending rate has a positive and significant impact on AGO.

However, the $\mathrm{R}^{2}$ which measures the goodness of fit has a value of 0.650051 and adjusted $\mathrm{R}$-squared of about $61 \%$ meaning that over $61 \%$ of the total variation in AGO is explained by the explanatory variables. Fstatistic has a p-value of 0.000001 , this is significant at $5 \%$ meaning that all the independent variables (CPS, INF and LDR) can influence AGO.

The Result of Unit Root Test

Table 3.0 Unit Root Test

\begin{tabular}{|l|l|l|l|l|l|}
\hline Variable & ADF Statistical Level & $\begin{array}{l}1 \% \text { Critical } \\
\text { Level }\end{array}$ & $\begin{array}{l}5 \% \text { Critical } \\
\text { Level }\end{array}$ & $\begin{array}{l}10 \% \text { Critical } \\
\text { Level }\end{array}$ & $\begin{array}{l}\text { Order of Co- } \\
\text { integration }\end{array}$ \\
\hline LogAGO & -3.738739 & -3.653730 & -2.957110 & -2.617434 & $1(1)$ \\
\hline LogCPS & -5.111396 & -3.653730 & -2.957110 & -2.617434 & $1(1)$ \\
\hline LogINF & -5.045520 & -3.646342 & -2.954021 & -2.615817 & $1(0)$ \\
\hline LogLDR & -3.454220 & -3.670170 & -2.963972 & -2.621007 & $1(0)$ \\
\hline
\end{tabular}

Source: Author's Estimation Using E-View 9, (2020)

Table 2 shows the result of unit root test using Augmented Dickey Fuller approach. The result reveals that INF and LDR are stationary at level that is 1(0), while AGO and CPS are integrated of order one that is 1(1). Since not all the variables are in the same order of integration then, Autoregressive Distributed Lag (ARDL) bound test will be adopted.

\section{ARDL Bound Test}

Based on the lag length selection criteria, it shows that the optimum number of lag suitable in testing the impacts of bank credit on real sector growth is one.

Table 4.0 Bound Test

\begin{tabular}{|l|l|l|}
\hline Test Statistics & Value & K \\
\hline F-statistics & 19.97956 & 3 \\
\hline Critical Value Bound & \multicolumn{2}{|l|}{} \\
\hline Significance & I0 Bound & I1 Bound \\
\hline $10 \%$ & 2.37 & 3.2 \\
\hline $5 \%$ & 2.79 & 3.67 \\
\hline $2.5 \%$ & 3.15 & 4.08 \\
\hline $1 \%$ & 3.65 & 4.66 \\
\hline
\end{tabular}

Source: Authors Computation, (2020)

Table 4.0 shows the F-statistic value of 19.97956 and the critical value at the lower and upper bounds are 2.79 and 3.67 which connotes that there is long-run relationship among the variables used in the study. 


\section{Result of Impulse Response through ECM Response of LOGCPS to LOGAG}
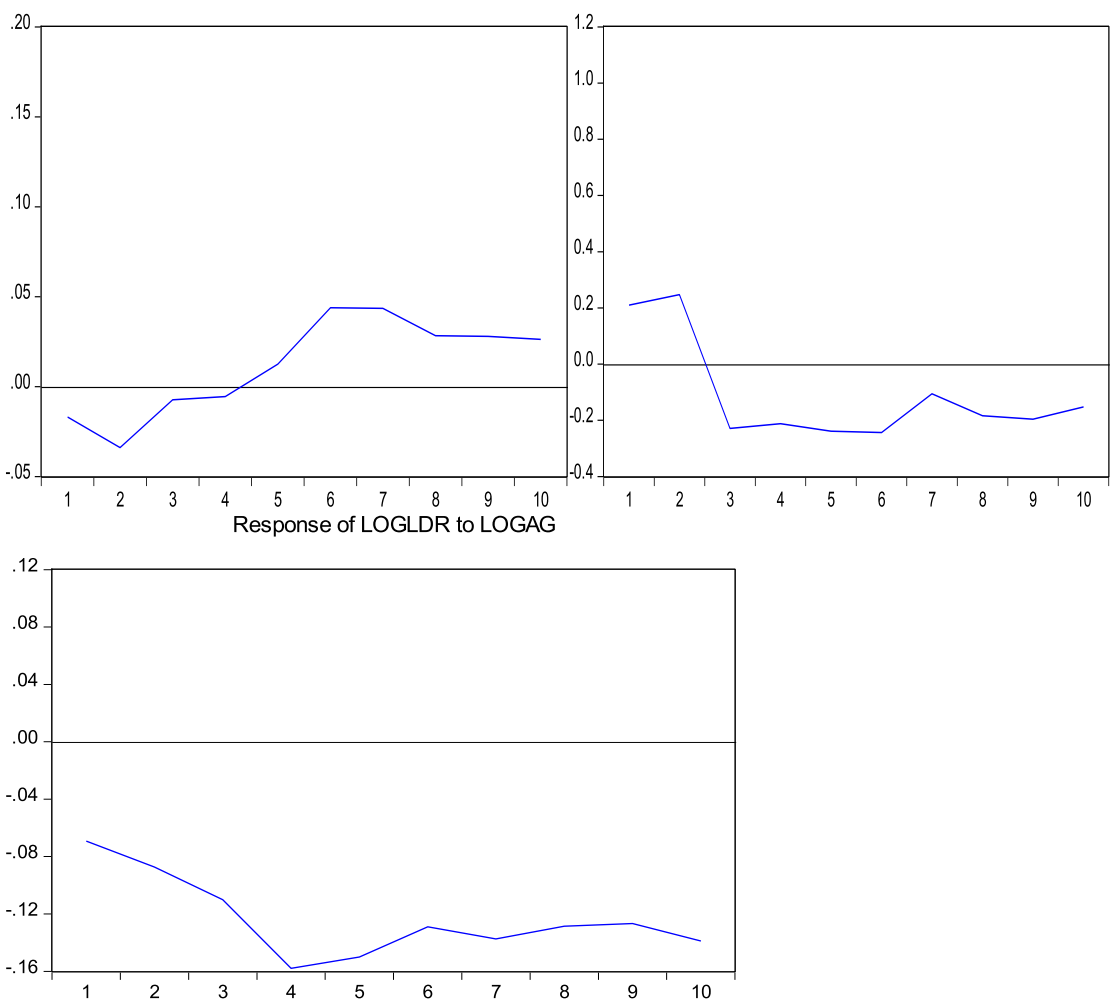

Source: Author's Design (2020)

Figure 1.0

Figure 2.0 shows the response of bank credit variables to variations in manufacturing output shows that at the beginning of the period, CPS is negative, then became positive at the medium term and stayed positive throughout the period. INF was positive in the short run, then negative and maintain negative trend in the long run. Whereas, LDR was negative and move further away with negative trend throughout the period.

Variance Decomposition Result

Table 5.0 Variance Decomposition

\begin{tabular}{|l|l|l|l|l|l|}
\hline Period & S.E. & AGO & CPS & INF & LDR \\
\hline 1 & 0.087195 & 100.0000 & 0.000000 & 0.000000 & 0.000000 \\
\hline 2 & 0.156149 & 96.93639 & 1.669163 & 0.752548 & 0.641896 \\
\hline 3 & 0.210797 & 95.90427 & 1.279976 & 2.296687 & 0.519068 \\
\hline 4 & 0.255159 & 92.03069 & 1.020521 & 6.588889 & 0.359895 \\
\hline 5 & 0.291212 & 86.92119 & 1.048798 & 11.67534 & 0.354678 \\
\hline 6 & 0.323415 & 83.84783 & 1.197977 & 14.58037 & 0.373824 \\
\hline 7 & 0.355240 & 81.53728 & 1.535400 & 16.60401 & 0.323306 \\
\hline 8 & 0.386513 & 78.74325 & 1.875018 & 19.08071 & 0.301013 \\
\hline 9 & 0.414967 & 76.62921 & 2.037853 & 21.05004 & 0.282902 \\
\hline 10 & 0.441578 & 75.13716 & 2.178445 & 22.42630 & 0.258092 \\
\hline
\end{tabular}

Source: Authors Computation, (2020)

From Table 5.0, it shows that INF in the short-run reveals higher variation of $2.3 \%$ (Period 3 ) to agricultural output (AGO), followed by CPS with $1.28 \%$ and then LDR with $0.52 \%$ to agricultural output (AGO). The longrun (period 10) variation followed the same order like the short run, INF maintain its position with $22.43 \%$, followed by CPS with $2.18 \%$ and lastly LDR $0.26 \%$ variation.

\section{Manufacturing Sector}

Descriptive Analysis

Result of the descriptive analysis shows that all the variables are positively skewed. Kurtosis statistic shows that MANO, INF and LDR are leptokurtic while CPS is platykurtic in nature. The Jarque-Bera statistic reveals that CPS is normally distributed while MANO, INF and LDR are not normally distributed during the study period. 
Ordinary Least Square Result

The result shows that the beta coefficient of MANO is negative at constant of -6.602613 which means that when all variables are held constant; there will be a negative variation to the tune of -6.602613 units in MANO. The coefficient value of credit to private sector (CPS) is 3.418216 with P-value of 0.0000 meaning that CPS has a positive and significant impact on MANO. INF has a coefficient value and P-value of -0.236011 and 0.1803 , which means that inflation rate impacted negatively and insignificantly on MANO, when lending rate has a coefficient value of 2.598781 and P-value of 0.0206 . This implies that lending rate has a positive and significant impact on MANO.

$\mathrm{R}^{2}$ has a value of 0.702630 with adjusted $\mathrm{R}$-squared of about $67 \%$ meaning that over $67 \%$ of the total variation in MANO is explained by the independent variables. F-statistic has a p-value of 0.000000 , this is significant at 5\% meaning that all the independent variables (CPS, INF and LDR) can influence MANO.

The Result of Unit Root Test

Table 6.0 Unit Root Test

\begin{tabular}{|l|l|l|l|l|l|}
\hline Variable & $\begin{array}{l}\text { ADF Statistical } \\
\text { Level }\end{array}$ & $\begin{array}{l}1 \% \text { Critical } \\
\text { Level }\end{array}$ & $\begin{array}{l}5 \% \text { Critical } \\
\text { Level }\end{array}$ & $\begin{array}{l}10 \% \text { Critical } \\
\text { Level }\end{array}$ & $\begin{array}{l}\text { Order of Co- } \\
\text { integration }\end{array}$ \\
\hline LogMANO & -3.654322 & -3.653730 & -2.957110 & -2.617434 & $1(1)$ \\
\hline LogCPS & -5.111396 & -3.653730 & -2.957110 & -2.617434 & $1(1)$ \\
\hline LogINF & -5.045520 & -3.646342 & -2.954021 & -2.615817 & $1(0)$ \\
\hline LogLDR & -3.454220 & -3.670170 & -2.963972 & -2.621007 & $1(0)$ \\
\hline
\end{tabular}

Source: Author's Estimation Using E-View 9, (2020)

The result of Augmented Dickey Fuller unit root test reveals that INF and LDR are stationary at level that is $1(0)$, while other variables became stationary after $1^{\text {st }}$ difference. Since the order cointegration are not the same, then Autoregressive Distributed Lag (ARDL) bound test is adopted.

\section{ARDL Bound Test}

Based on the lag length selection criteria, it shows that the optimum number of lag suitable for the test is 2 .

\section{Result of Bound Test}

Table 7.0 Bound Test

\begin{tabular}{|l|l|l|}
\hline Test Statistics & Value & $\mathrm{K}$ \\
\hline F-statistics & 35.61713 & 3 \\
\hline Critical Value Bound & \multicolumn{2}{|l|}{} \\
\hline Significance & I0 Bound & I1 Bound \\
\hline $10 \%$ & 2.37 & 3.2 \\
\hline $5 \%$ & 2.79 & 3.67 \\
\hline $2.5 \%$ & 3.15 & 4.08 \\
\hline $1 \%$ & 3.65 & 4.66 \\
\hline
\end{tabular}

Source: Authors Computation, (2020)

Table 7.0 shows the F-statistic value of 35.61713 and the critical value at the lower and upper bounds are 2.79 and 3.67 , this shows that there is long-run relationship among the variables. 


\section{Result of Impulse Response through ECM}
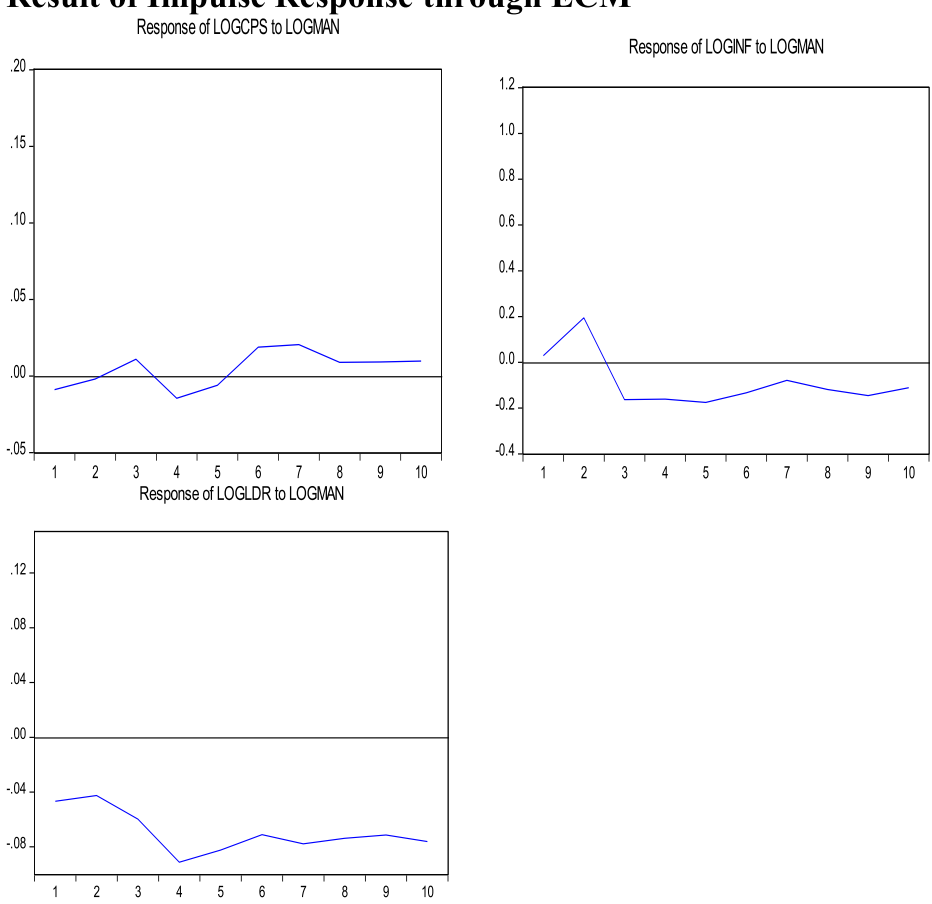

\section{Source: Author's Design (2020)}

\section{Figure 2.0}

The above figure shows the response of Credit to Private Sector (CPS), Inflation Rate (INF) and Lending Rate (LDR) to the variation in manufacturing output. It shows that at the beginning of the period, CPS moves from negative to positive in the short run and stayed positive throughout the period. INF was positive in the short run, then negative and maintain negative trend in the long run. Whereas, LDR was negative and move further away with negative trend throughout the period.

Variance Decomposition Result

Table 8.0 Variance Decomposition

\begin{tabular}{|l|l|l|l|r|c|}
\hline Period & \multicolumn{1}{|l|}{ S.E. } & LogMANO & LogCPS & LogINF & \multicolumn{1}{l|}{ LogLDR } \\
\hline 1 & 0.088675 & 100.0000 & 0.000000 & 0.000000 & 0.000000 \\
\hline 2 & 0.194077 & 87.44303 & 2.112946 & 1.630215 & 8.813808 \\
\hline 3 & 0.266752 & 84.00443 & 4.281962 & 2.082003 & 9.631604 \\
\hline 4 & 0.301238 & 83.07937 & 3.638030 & 3.864175 & 9.418423 \\
\hline 5 & 0.319966 & 81.70689 & 3.335920 & 5.654411 & 9.302782 \\
\hline 6 & 0.340195 & 78.30536 & 2.952350 & 10.10869 & 8.633602 \\
\hline 7 & 0.361369 & 72.95703 & 2.750465 & 16.48264 & 7.809860 \\
\hline 8 & 0.381467 & 68.52042 & 2.608179 & 21.60498 & 7.266421 \\
\hline 9 & 0.410795 & 61.45460 & 2.455384 & 29.58252 & 6.507499 \\
\hline 10 & 0.440127 & 54.85699 & 2.255938 & 37.11935 & 5.767731 \\
\hline
\end{tabular}

Source: Authors Computation, (2020)

From Table 8.0, it shows that LDR in the short-run reveals higher variation of 9.63\% (Period 3) to manufacturing output (MANO), followed by CPS with $4.28 \%$ and then INF with $2.08 \%$ to manufacturing output (MANO). In the long-run (period 10), the variation order was altered, INF exhibits higher variation with $37.12 \%$, followed by LDR with $5.77 \%$ and lastly CPS $2.26 \%$ variation.

\section{Discussion of Findings}

Agricultural Sector

Arising from the various tests conducted on the variables, the descriptive analysis from kurtosis statistic showed that AGO was mesokurtic that is normally distributed; INF and LDR were leptokurtic, meaning that there were more higher values than the mean. CPS was platycurtic that is there were more lower values than the mean. Jarque-Bera statistic revealed that AG and CPS mirror normal distribution while INF and LDR are not normally distributed.

The result of the OLS showed that CPS is positively and significantly related to AGO. This implies that the 
availability of more credit to the private sector will increase output of agricultural sector. Inflation rate was negative and insignificantly related to AGO, the implication is that, high inflation rate will reduce the output of agricultural sector if not controlled. Meanwhile, LDR was found to be positively and significantly related to agricultural sector. This might be due to efficient usage of the borrowed. This is contrary to the a priori expectation.

The result of the ARDL from the Bound Test showed that there is long run relationship between bank credit and agricultural output. Whereas, the result from vector error correction through impulse response function and variance decomposition tests revealed that the credit to private sector and inflation rate move in positive and negative directions but closer to zero. While lending rate moves in negative direction away from zero. The variance decomposition result showed that inflation rate accounted for the highest variation in both the short-run and the long run, followed by credit to private sector and lending rate respectively.

\section{Manufacturing Sector}

Result of the descriptive analysis from kurtosis statistic showed that MANO, INF and LDR are leptokurtic, meaning that there were more higher values than the mean. CPS was platycurtic that is there were more lower values than the mean. Jarque-Bera statistic reveals that CPS is normally distributed while MANO, INF and LDR are not normally distributed.

However, the result of the OLS and ARDL through the Bound Test revealed similar outcome with that of agricultural sector. Whereas, the result from ECM through impulse response function and variance decomposition tests revealed that the credit to private sector and inflation rate move in positive and negative directions but closer to zero. While lending rate moves in negative direction away from zero. The variance decomposition result showed that lending rate accounted for the highest variation, followed by credit to private sector and inflation rate in the short-run, whereas inflation rate exhibits the highest variation in the long run, followed by lending rate and credit to private sector respectively.

\section{Conclusion and Recommendations}

In line with the findings, the study concluded that the real sector (agricultural and manufacturing sector) is positively influenced by credit to private sector with little contribution. This implies that there is need to make more credit availability to the real sector in order to increase output. Inflation rate is inversely related to both agricultural and manufacturing sectors. In order to ensure increase in the contribution of the real sector to GDP, there is need to drastically reduce the prevailing inflation rate. Lastly, the lending rate responded negatively and moved further away from zero in the impulse from the real sector. This shows that the CBN should ensure a workable lending rate that will boost real sector output.

In accordance with the findings and conclusion drawn from this study, the study therefore recommended as follows:

i. Central bank of Nigeria should increase the proportion of credit to private sector and at the same time control lending rate so as to increase the output of the real sector in Nigeria.

ii. Machinery to meet up with the targeted inflation rate must be put in place; this will reduce cost of production and thereby increase output of the real sector.

\section{REFERENCES}

Adenugba, A. A. (2015). Banking System Credit as an Instrument of Economic Growth in Nigeria. European Journal of Economics, Business and Accountancy 3(7) 1-23

Aiyedogbon, J. O., \&Anyanwu, S. O. (2015). Macroeconomic Determinants of Industrial Development in Nigeria. Nile Journal of Business and Economics, (1), 37-46.

Ajayi, D. D. (2000). 'The Determinants of the Volume of Production Subcontracting in Nigeria'. Nigeria Journal of Economic and Social Studies (NJESS), 42 (1), 1-11

Ananzeh, I. N. (2016). Relationship between Bank Credit and Economic Growth: Evidence from Jordan International Journal of Financial Research 7(2)

Andabai, P. W. \&Eze, G. P. (2018). Bank Credit and Manufacturing Sector Growth in Nigeria: A Causality Investigation. International Journal of Economics, Commerce and Management United Kingdom, 6(3), 326

CBN (2003). Contemporary Economic Policy Issues in Nigeria, CBN Abuja

Central Bank of Nigeria (2013). Modeling the Real Sector of the Nigerian Economy. Publication of CBN Research Department.

Domar, E. (1946). Capital expansion, rate of growth and employment. Econometrica, 14(2), 137-147.

Ebele, E. J. \& Iorember, P. T. (2016). Commercial Bank Credit and Manufacturing Sector Output in Nigeria. Journal of Economics and Sustainable Development 7(16), 189

Edirisuriya, P. (2008). 'Effects of Financial Sectors in SRI Lanka: Evidence from the Banking Sector'. Asia Pacific Journal of Finance and Banking Research, 1(1). 
Emecheta, B. C. \& Ibe R. C. (2014). Impact of Bank Credit on Economic Growth in Nigeria: Application of Reduced Vector Autoregressive (VAR) Technique. European Journal of Accounting Auditing and Finance Research 2(9), 11-21

Harrod, R. F. (1939). An essay in dynamic theory. The Economic Journal, 44, 14-33.

Kirk-Greene, A. \& Rimmer, D. (1981), Nigeria since 1970: A Political \& Economic Outline. London, Hodder \& Stoughton

Lorenzo, D. \& Daryna, G. (2015). Financial development, real sector, and economic growth. Preprint submitted to Elsevier

McKinnon, R. (1973). Money and Capital in Economic Development. The Brooking Institute, Washington DC.

Oni, I. O. Akinlo, A. E. \&Oladepo, E. D. (2014). Impact of Bank Credit on the Real Sector: Evidence from Nigeria. Global Journal of Business Research 8(3)

Shaw, E. (1973). Financial Deepening in Economic Development. Oxford University Press, New York. 